\title{
A new Liopropoma sea bass (Serranidae, Epinephelinae, Liopropomini) from deep reefs off Curaçao, southern Caribbean, with comments on depth distributions of western Atlantic liopropomins
}

\author{
Carole C. Baldwin ${ }^{1, \dagger}$, D. Ross Robertson ${ }^{2, \neq}$ \\ I Department of Vertebrate Zoology, National Museum of Natural History, Smithsonian Institution, Washington, \\ DC 205602 Smithsonian Tropical Research Institute, Balboa, Republic of Panamá \\ † http://zoobank.org/B21379DC-6FF2-4C99-89FC-F9FD5B30911D \\ ‡ http://zoobank.org/ADOD80E1-BEAB-4F95-8594-3B1E5774FA18 \\ Corresponding author: Carole C. Baldwin (baldwinc@si.edu)
}

Academic editor: N. Bogutskaya | Received 12 February 2014 | Accepted 29 April 2014 | Published 15 May 2014

http://zoobank.org/BA212ABD-69C4-4E4B-8E6D-C59C10754498

Citation: Baldwin CC, Robertson RD (2014) A new Liopropoma sea bass (Serranidae, Epinephelinae, Liopropomini) from deep reefs off Curaçao, southern Caribbean, with comments on depth distributions of western Atlantic liopropomins. ZooKeys 409: 71-92. doi: 10.3897/zookeys.409.7249

\begin{abstract}
Collecting reef-fish specimens using a manned submersible diving to $300 \mathrm{~m}$ off Curaçao, southern Caribbean, is resulting in the discovery of numerous new fish species. The new Liopropoma sea bass described here differs from other western Atlantic members of the genus in having VIII, 13 dorsal-fin rays; a moderately indented dorsal-fin margin; a yellow-orange stripe along the entire upper lip; a series of approximately 13 white, chevron-shaped markings on the ventral portion of the trunk; and a reddish-black blotch on the tip of the lower caudal-fin lobe. The new species, with predominantly yellow body and fins, closely resembles the other two "golden basses" found together with it at Curaçao: L. aberrans and L. olneyi. It also shares morphological features with the other western Atlantic liopropomin genus, Bathyanthias. Preliminary phylogenetic data suggest that western Atlantic liopropomins, including Bathyanthias, are monophyletic with respect to Indo-Pacific Liopropoma, and that Bathyanthias is nested within Liopropoma, indicating a need for further study of the generic limits of Liopropoma. The phylogenetic data also suggest that western Atlantic liopropomins comprise three monophyletic clades that have overlapping depth distributions but different depth maxima (3-135 m, 30-150 m, 133-411 m). The new species has the deepest depth range (182-241 m) of any known western Atlantic Liopropoma species. Both allopatric and depth-mediated ecological speciation may have contributed to the evolution of western Atlantic Liopropomini.
\end{abstract}

Copyright C.C. Baldwin I, D.R. Robertson. This is an open access article distributed under the terms of the Creative Commons Attribution License (CC BY 4.0), which permits unrestricted use, distribution, and reproduction in any medium, provided the original author and source are credited. 


\section{Keywords}

Liopropoma aberrans, Liopropoma olneyi, submersible, Substation Curaçao, Deep Reef Observation Project (DROP), DNA barcoding, phylogeny, modes of speciation

\section{Introduction}

Submersible diving to $300 \mathrm{~m}$ off Curaçao in the southern Caribbean as part of the Smithsonian Institution's Deep Reef Observation Project (DROP) is expanding our knowledge of the deep-reef Caribbean fish fauna (Baldwin and Robertson 2013, Baldwin and Johnson 2014). Recent collections of fishes included multiple individuals of what we initially identified as Liopropoma aberrans (Poey 1860) based on their predominantly golden color pattern. Subsequent analysis of mitochondrial DNA sequences (COI) from those specimens, detailed morphological examination of the preserved voucher specimens, and the discovery of consistent patterns of variation in coloration in photographs of vouchers taken prior to preservation led to the description of some of those individuals as a new species, L. olneyi Baldwin \& Johnson, 2014. Additional genetic and morphological data indicate that the "golden basses" off Curaçao, in fact, comprise three species, $L$. aberrans, $L$. olneyi, plus one undescribed species. Herein we describe this third species, Liopropoma santi sp. $\mathrm{n}$.

Liopropoma (Atlantic and Pacific), Bathyanthias (western Atlantic), and the monotypic Rainfordia (Indo-Pacific) form the monophyletic epinepheline serranid tribe Liopropomini (Baldwin and Johnson 1993). Twelve species of liopropomins currently are known from the western Atlantic, including the new species described herein: seven species of Liopropoma, four species of Bathyanthias, and a putative new species of the latter genus that we refer to here. These western Atlantic liopropomin species inhabit both shallow $(<50 \mathrm{~m})$ and deep (to $411 \mathrm{~m})$ reefs in Caribbean and adjacent waters. To compare species depth preferences, we use the known depth maximum and minimum for each species. To investigate how deep and shallow species are interrelated, we use the COI data to hypothesize the phylogeny of the group and then analyze the results in the context of the known depth distributions of the various species. Based on these results, we comment on possible modes of speciation in western Atlantic liopropomins.

\section{Materials and methods}

The manned submersible Curasub (http://www.substation-Curacao.com) was employed to collect fishes and invertebrates during various field periods between 2011 and 2013. Fish specimens were collected using the fish anesthetic quinaldine pumped from a reservoir through a tube attached to one hydraulic arm of the sub and a suction hose (that uses the same pump as the anesthetic-delivery apparatus) attached to the other arm. The latter empties into a vented plexiglass cylinder attached to the outside of the sub. At the surface, the specimens were measured, photographed, tissue sampled (muscle 
biopsy from right side) and preserved. They were later x-rayed with a digital radiography system. Counts and measurements included in the description follow Hubbs and Lagler (1958) and Randall and Taylor (1988). Measurements were made to the nearest $0.1 \mathrm{~mm}$ with an ocular micrometer fitted into a Wild stereomicroscope (smallest specimen) or with needle-point dial calipers. Institutional abbreviations follow Sabaj Pérez (2012).

Tissue samples for DNA Barcoding were stored in saturated salt-DMSO (dimethyl sulfoxide) buffer (Seutin et al. 1991). DNA extraction, PCR, sequencing cytochrome c oxidase subunit I (COI), and editing COI sequences were performed as outlined by Weigt et al. (2012). A neighbor-joining tree (Saitou and Nei 1987) was generated using PAUP*4.1 (Swofford 2002) on an analysis of Kimura two-parameter distances (Kimura 1980). The neighbor-joining tree shows genetic distances in COI among individuals and how they cluster into genetically distinct lineages, which, in teleost fishes, correspond well with species (e.g. Baldwin and Weigt 2012, Weigt et al. 2012). Interspecific phylogenetic relationships were hypothesized for western Atlantic liopropomins and three Indo-Pacific species of Liopropoma based on maximum parsimony analysis of the $\mathrm{COI}$ sequences using heuristic searches in PAUP*4.1. Characters were equally weighted and left unordered. The resulting equally parsimonious trees were summarized using the strict consensus method. Outgroups for both analyses were two members of the sister group of the Liopropomini - Grammistes sexlineatus (Thunberg, 1782) and Rypticus carpenteri Baldwin \& Weigt, 2012, of the tribe Grammistini (Baldwin and Johnson 1993), and the trees were rooted on a more distant outgroup, Scorpaena plumieri of the family Scorpaenidae. We follow Johnson (1983) and Baldwin and Johnson (1993) in recognizing a monophyletic family Serranidae and subfamily Epinephelinae pending resolution of serranid relationships in light of conflicting hypotheses based on molecular data (e.g., Smith and Craig 2007, Betancur et al. 2013, Near et al. 2013).

The label for each entry on the neighbor-joining tree is an assigned DNA number, and we include that number in the designation of type specimens and in some figure captions. Abbreviations used in DNA numbers are as follows: BAH-Bahamas, BLZBelize, CUR-Curacao, FLST-Florida Straits, FWRI-Florida Wildlife Research Institute, MBIO-Moorea Biocode Project, MCgroup-Matthew Craig, MOC-Miguel Oliver Caribbean Cruise, MOOP-Moorea Deep Reef, TOB-Tobago. GenSeq nomenclature for DNA sequences (Chakrabarty et al. 2013) and GenBank information are presented along with museum catalog numbers for voucher specimens in the Appendix.

\section{Results}

The neighbor-joining tree (Fig. 1) shows how individual specimens of western Atlantic Liopropoma sort into genetic lineages based on similarity in COI sequences. Lineages correlate well with currently recognized species. Genetic distance in COI between pairs of species of western Atlantic Liopropoma ranges from 5-18\%, and distance between $L$. santi sp. n., and other western Atlantic Liopropoma species is 13-18\% (Table 1). Average intraspecific variation for western Atlantic Liopropoma is $0-0.3 \%, 0.2 \%$ for L. santi. 


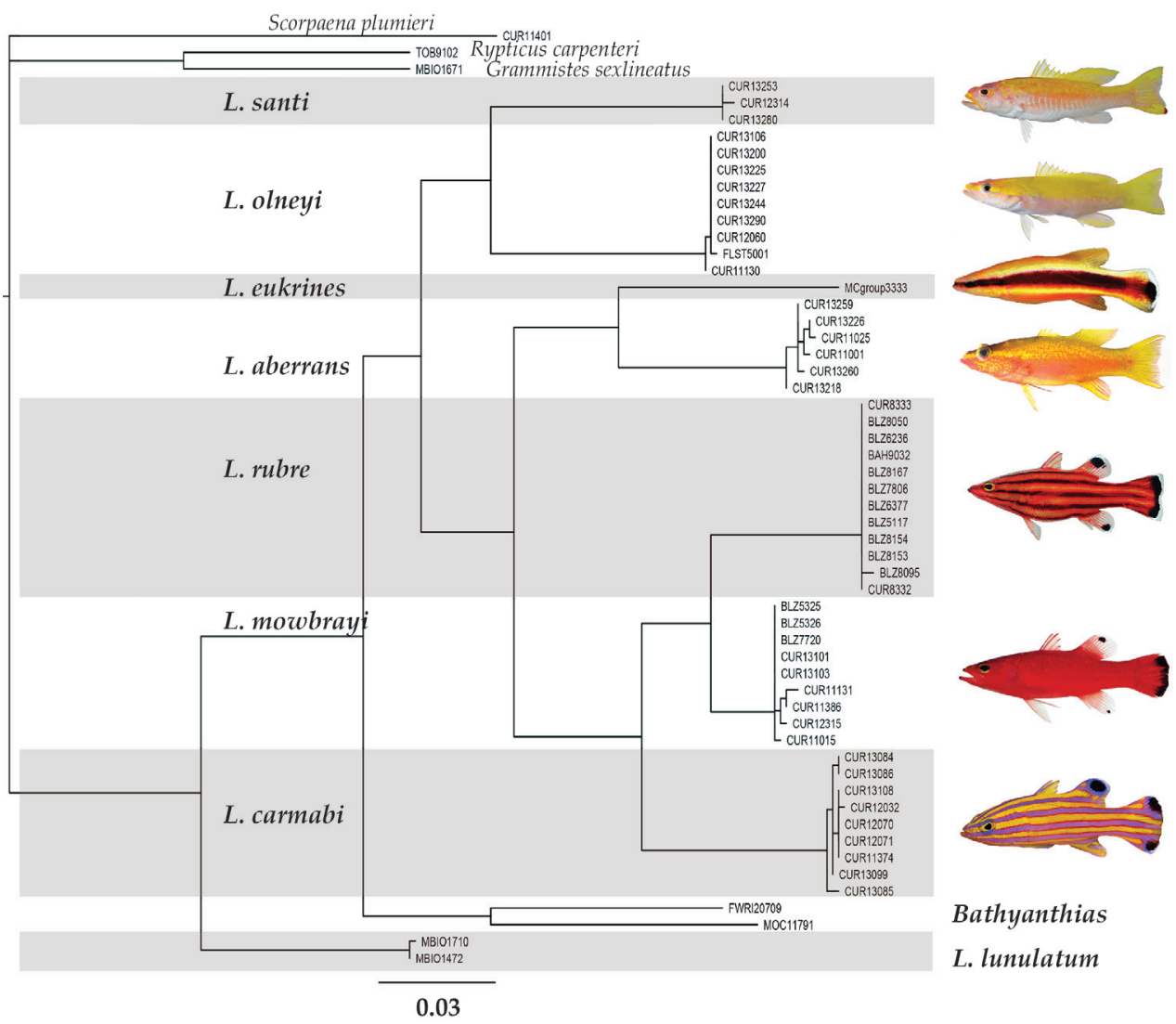

Figure I. Neighbor-joining tree derived from COI sequences for western Atlantic Liopropoma, the IndoPacific L. lunulatum, and related taxa. The tree was rooted on Scorpaena plumieri. Divergence represented by scale bar $=3 \%$. Photographs of $L$. rubre and L. mowbrayi by James Van Tassell and Ross Robertson.

\section{Liopropoma santi sp. n.}

http://zoobank.org/83D20375-39CA-457D-8D54-127ACC3ED0B7

http://species-id.net/wiki/Liopropoma_santi

Figs 2-4, Spot-tail Golden Bass

Type locality. Curaçao, southern Caribbean

Holotype. USNM 426811, 116 mm SL, DNA \#CUR 13253, Curasub submersible, sta. 13-14, southern Caribbean, Curaçao, off Substation Curaçao downline, near $12^{\circ} 05.069^{\prime} \mathrm{N}, 68^{\circ} 53.886^{\prime} \mathrm{W}, 241 \mathrm{~m}$, quinaldine, 9 Aug 2013, C. C. Baldwin, D. R. Robertson, A. Driskell, B. van Bebber.

Paratypes. USNM 426813, 76.2 mm SL, DNA \#CUR 13280, Curasub submersible, sta. 13-19, southern Caribbean, Curaçao, Playa Forti, Westpoint, $12^{\circ} 22.001^{\prime} \mathrm{N}, 69^{\circ} 9.005$ W, 182 m, quinaldine, 15 Aug 2013, A. Schrier, N. Knowlton, R. Sant, B. van Bebber. USNM 414824, 42.0 mm SL, DNA \#CUR 12314, Curasub submersible, sta. 12-19, 
Table I. Average (and range) Kimura two-parameter distance summary for species of western Atlantic Liopropoma (7), Indo-Pacific Liopropoma (1), western Atlantic Bathyanthias (2), and outgroups Grammistes, Rypticus, and Scorpaena based on cytochrome c oxidase I (COI) sequences of individuals represented in the neighbor-joining tree in Figure 1. Intraspecific averages are shown in bold. "na" = not applicable $(\mathrm{n}=1)$.

\begin{tabular}{l|l|l|l|l}
\hline & L. aberrans & L. carmabi & L. eukrines & L. lunulatum \\
\cline { 2 - 5 } & W. Atl. & W. Atl. & W. Atl. & Indo-Pacific \\
\cline { 2 - 5 } & $(\mathrm{n}=6)$ & $(\mathrm{n}=9)$ & $(\mathrm{n}=1)$ & $(\mathrm{n}=2)$ \\
\hline L. aberrans & $\mathbf{0 . 3}(\mathbf{0}-\mathbf{0 . 6})$ & & & \\
\hline L. carmabi & $14.6(14.2-15.2)$ & $\mathbf{0 . 2}(\mathbf{0}-\mathbf{0 . 6})$ & & \\
\hline L. eukrines & $10.5(10.2-10.8)$ & $15.1(14.8-15.6)$ & na & \\
\hline L. lunulatum & $14.8(14.6-15.1)$ & $16.4(16.1-16.9)$ & $14(14.0-14.1)$ & $\mathbf{0 . 1}(\mathbf{0}-\mathbf{0 . 2})$ \\
\hline L. mowbrayi & $12.2(11.9-12.5)$ & $8.6(8.2-9.1)$ & $13.5(13.4-13.9)$ & $15.5(15.3-15.8)$ \\
\hline L. olneyi & $11.8(11.5-12.1)$ & $13.6(13.4-14.2)$ & $13(12.8-13.1)$ & $14.7(14.4-14.9)$ \\
\hline L. rubre & $11.9(11.5-12.4)$ & $10.5(10.1-10.9)$ & $12.9(12.8-13.3)$ & $15.8(15.3-16)$ \\
\hline L. santi sp. $\mathbf{n}$. & $16.2(16.0-16.7)$ & $17.6(17.1-18.4)$ & $15.2(15.0-15.6)$ & $16.4(16.0-16.9)$ \\
\hline B. mexicanus & $16.1(15.8-16.4)$ & $17.6(17.1-18.4)$ & $15.2(15.0-15.6)$ & $16.4(16.0-16.9)$ \\
\hline Bathyanthias sp & $16.8(16.5-17)$ & $15.4(15.2-15.7)$ & $15.4(-)$ & $16(15.9-16.1)$ \\
\hline G. sexlineatus & $18.6(18.3-18.8)$ & $17.9(17.7-18.4)$ & $18(-)$ & $17(16.9-17.1)$ \\
\hline R. carpenteri & $17.3(17.1-17.5)$ & $17.9(17.9-18.1)$ & $14.8(-)$ & $15.4(15.4-15.5)$ \\
\hline S. plumieri & $21.4(21.2-21.5)$ & $21.6(21.4-22)$ & $20.9(-)$ & $19.8(19.7-19.8)$ \\
\hline
\end{tabular}

\begin{tabular}{l|l|l|l|l}
\hline & L. mowbrayi & L. olneyi & L. rubre & L. santi sp. $\mathbf{~}$ \\
\cline { 2 - 5 } & W. Atl. & W. Atl. & W. Atl. & W. Atl. \\
\cline { 2 - 5 } & $(\mathrm{n}=9)$ & $(\mathrm{n}=9)$ & $(\mathrm{n}=12)$ & $(\mathrm{n}=3)$ \\
\hline L. mowbrayi & $\mathbf{0 . 2}(\mathbf{0}-\mathbf{0 . 6})$ & & & \\
\hline L. olneyi & $13.3(13.0-13.7)$ & $\mathbf{0}(\mathbf{0}-\mathbf{0 . 3})$ & & \\
\hline L. rubre & $5.7(5.3-6.0)$ & $12.5(12.2-13.2)$ & $\mathbf{0}(\mathbf{0}-\mathbf{0 . 3})$ & \\
\hline L. santi sp. $\mathbf{n}$. & $15.5(14.8-16.5)$ & $13.3(13.0-13.5)$ & $16.4(15.9-17.6)$ & $\mathbf{0 . 2}(\mathbf{0 . 0}-\mathbf{0 . 3})$ \\
\hline B. mexicanus & $13.9(13.8-14.1)$ & $13.4(13.4-13.5)$ & $13.8(13.7-14.3)$ & $16.2(15.9-16.9)$ \\
\hline Bathyanthias sp & $14.8(14.6-14.9)$ & $15.2(15.1-15.4)$ & $14.6(14.5-14.8)$ & $16.4(16.2-16.7)$ \\
\hline G. sexlineatus & $18.1(18.0-18.5)$ & $18.9(18.7-18.9)$ & $18(17.8-18.3)$ & $20.8(20.5-21.5)$ \\
\hline R. carpenteri & $16.8(16.6-17)$ & $18.6(18.4-18.6)$ & $17.4(17.2-17.5)$ & $17.5(17.5-17.6)$ \\
\hline S. plumieri & $19.7(19.5-20.4)$ & $20.8(20.8)$ & $20.3(20.2-20.6)$ & $24.5(24.4-24.8)$ \\
\hline & & & &
\end{tabular}

\begin{tabular}{l|l|l|l|l|l}
\hline & B. mexicanus & Bathyanthias sp & G. sexlineatus & R. carpenteri & S. plumieri \\
\cline { 2 - 6 } & W. Atl. & W. Atl. & Indo-Pacific & W. Atl. & W. Atl. \\
\cline { 2 - 6 } & $(\mathrm{n}=1)$ & $(\mathrm{n}=1)$ & $(\mathrm{n}=1)$ & $(\mathrm{n}=1)$ & $(\mathrm{n}=1)$ \\
\hline B. mexicanus & na & & & & \\
\hline Bathyanthias sp & $13.7(-)$ & na & & & \\
\hline G. sexlineatus & $19.8(-)$ & $15.9(-)$ & na & & \\
\hline R. carpenteri & $18.9(-)$ & $16.8(-)$ & $13.2(-)$ & na & \\
\hline S. plumieri & $19.2(-)$ & $20.7(-)$ & $19.5(-)$ & $19.6(-)$ & na \\
\hline
\end{tabular}


southern Caribbean, Curaçao, east of Substation Curaçao downline, near $12^{\circ} 05.069^{\prime} \mathrm{N}$, 68 53.886'W, 209 m, 15 Aug 2012, C. C. Baldwin, B. Brandt, B. van Bebber.

Diagnosis. A liopropomin serranid with the following combination of characters: dorsal fin VIII,13; anal fin III, 8; pectoral fin 15; total gill rakers on first arch (including rudiments) 20-21; lateral-line scales 47-48; length of first dorsal spine 2.9-4.2\% SL; margin of spinous dorsal fin moderately indented posteriorly in adults (fourth spine $11-12 \%$ SL, fifth and sixth spines only slightly shorter than fourth-6.9-10\% SL); depth at origin of dorsal fin 23-26\% SL; least depth of caudal peduncle 11-13\% SL; orbit diameter 9.4-12\% SL; yellow-orange stripe externally on upper lip; series of approximately 13 white, chevron-shaped markings on ventral portion of trunk; reddish-black blotch on distal portion of lower caudal-fin lobe; inhabiting depths of 182-241 m.

Description. Counts and measurements of holotype, if different from those of paratypes, are given in parentheses. Dorsal-fin rays VIII, 13; anal-fin rays III, 8; pectoral-fin rays (both sides) 15; pelvic-fin rays I, 5; principal caudal-fin rays $9+8=17$; procurrent caudal-fin rays $9+9=18$; pored lateral-line scales 48 (47), two additional pored scales present on base of caudal fin not included in total count; scales from lateral line to dorsal-fin origin 3 or 4 (3); gillrakers on first arch, including rudiments, $6+14-15$ $(6+14)$; upper limb with 3 rudiments +3 rakers, lower limb with 11-13 rakers $+2-3$ rudiments, total 20-21 (20); vertebrae $10+14$.

Body proportions expressed as percentage of SL. Body depth at origin of dorsal fin 23-26 (26); body width just behind gill opening 11-14 (14); head length 37-39 (37); snout length 7.4-9.1 (9.1), relative length increasing with increasing SL; orbit diameter 9.4-12 (9.4) relative diameter decreasing with increasing SL; bony interorbital width 4.5-5.5 (5.5); upper-jaw length 16-18 (18); greatest depth of maxilla 5.0-6.1 (6.1); least caudal-peduncle depth 11-13 (13); caudal-peduncle length 22-24 (23); lengths of dorsal-fin spines: (I) 2.9-4.2 (4.2); (II) 11-12 (12); (III) 13-15 (14); (IV) 11-12 (11); (V) 6.9-10 (10); (VI) 6.9-8.2 (8.2); (VII) 5.0-7.5 (7.5); (VIII) 4.8-6.9 (6.9); longest dorsal soft ray the $11^{\text {th }}$, length $15-20$ (20); length of $3^{\text {rd }}$ anal-fin spine 6.9-9.3 (9.3); longest anal soft ray the $5^{\text {th }}$, length 15-17 (16); caudal-fin length $23-28$ (23), relative length decreasing with increasing SL; pectoral-fin length 27-30 (27), fin reaching vertical between anus and origin of anal fin, falling short of anal fin in all specimens; pelvic-fin length $18-20$ (19), fin reaching vertical through base of $6^{\text {th }}$ dorsal-fin spine, well short of anus.

Interorbital region flat to slightly convex; mouth oblique, maxilla reaching vertical beyond posterior border of pupil; prominent bony projection on posteroventral corner of maxilla; lower jaw slightly projecting. Anterior nostril in thin, membranous tube, nostril situated just posterior to groove between tip of snout and premaxilla; posterior nostril a simple opening, nostril situated close to orbit (the distance approximately 1.5 nostril diameters). Lateral line strongly arched above pectoral fin, highest point below fourth and fifth dorsal-fin spines.

Trunk covered with ctenoid scales, scales becoming weakly ctenoid anteriorly and cycloid on head. Head fully scaled except over branchiostegal area. Holotype with 

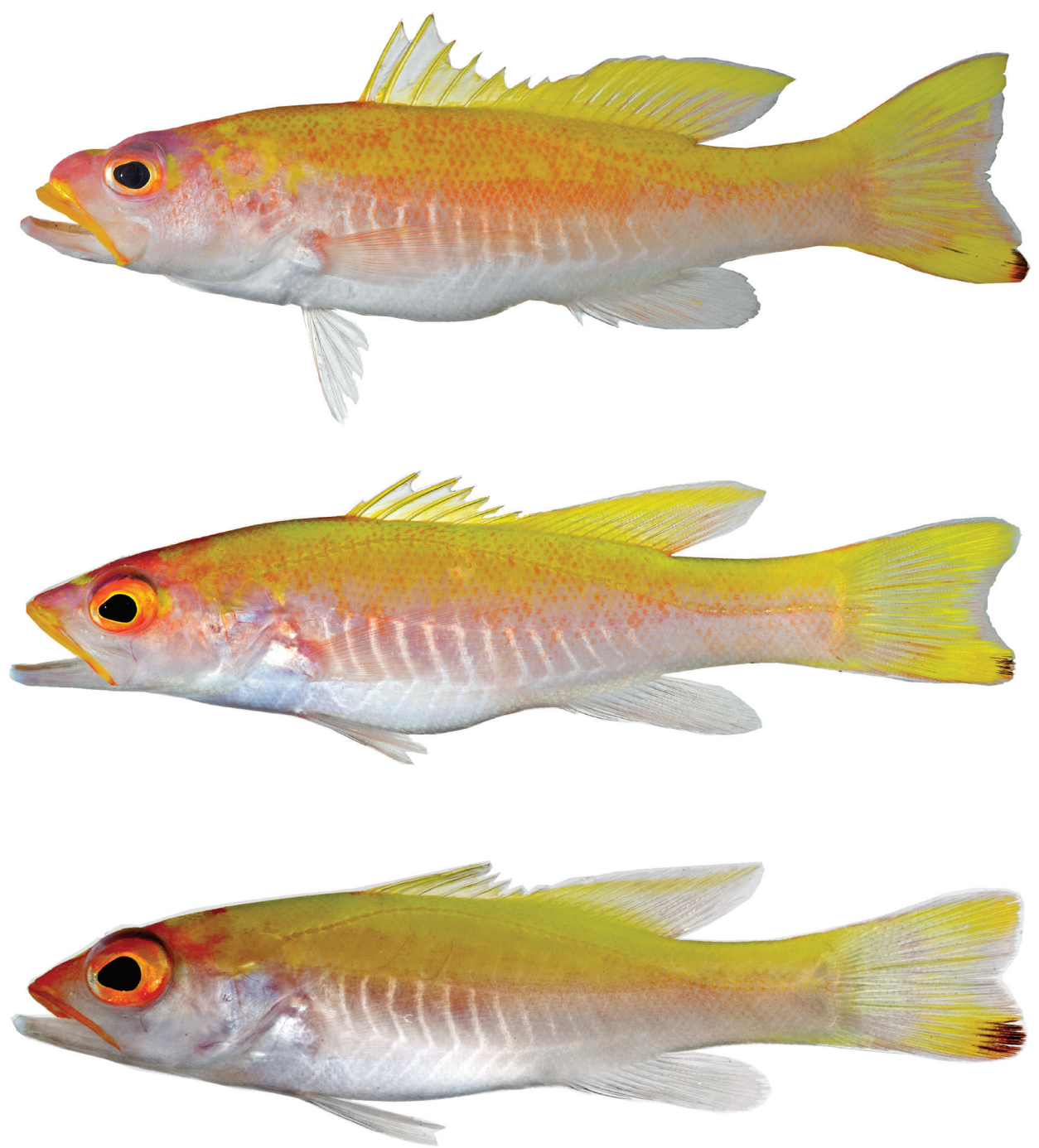

Figure 2. Liopropoma santi sp. n., type series: A USNM 426811, holotype, $116 \mathrm{~mm}$ SL, DNA \#CUR 13253 B USNM 426813, paratype, 76.2 mm SL, DNA \#CUR 13280 C USNM 414824, paratype, 42.0 mm SL, DNA \#CUR 12314.

short column of scales on dorsal-fin spines III and IV, scales on basal portion of membranes between spines VI and VIII, three rows of scales covering basal portion of soft dorsal fin, and some scales extending distally onto soft dorsal-fin membranes; paratypes with same squamation except no scales present on spinous dorsal fin, and 42.0$\mathrm{mm} S \mathrm{~L}$ paratype having only basal scale rows on soft dorsal fin. In holotype and larger paratype, anal fin with two or three rows of scales basally and additional scales that extend distally onto fin membranes and cover most of fin. In smaller paratype, scales confined to basal portion of fin. Caudal fin completely scaled in holotype except for 
distal tips of rays; larger paratype with scales covering only proximal half of fin; smaller paratype with scales confined to basal portion of fin. Scales present on pectoral-fin base, and elongate scales present on proximal portion of fin. Scales present on pelvicfin base and on proximal portion of fin; pelvic axillary scales present.

Jaw teeth small and depressible; upper and lower jaws with bands of villiform teeth, bands widest anteriorly, largest teeth in innermost row. Vomer with a chevronshaped patch of small teeth. Palatines with several rows of small teeth in a long, narrow band. Opercle with three flattened spines, only the middle one conspicuous. Margin of upper limb of preopercle and angle with small serrations, lower limb smooth.

Prior to preservation (Figs 2, 3), background color of upper portions of trunk and caudal peduncle yellow, grading to pale pink around midbody, then to white ventrally; no abrupt transitions between those colors; many individual scales on upper half of body marked with orange spots in adults, densely so in holotype; a series of about 13 narrow, bright-white, chevron-shaped bars that point posteriorly present on lower half of trunk, series extending from just behind pectoral-fin base to vertical through center or posterior portion of anal fin; upper arms of white bars more strongly defined; nape yellow from dorsal midline ventrally to about mid-eye level (with some orange spots on scales in adults), grading anteriorly into an irregularly shaped area of purplish-pink over and behind eye, on upper portion of iris, and on snout; a yellow blotch present behind center of eye (in adults) and a smaller one present on dorsal midline of snout just anterior to orbit; iris mostly orange-yellow, grading to fine inner yellow ring; prominent, mostly deep-yellow (adults) or mostly orange (juvenile) stripe along outside of entire upper lip, this pigment spreading slightly above lip along anterior half of jaw in adults and merging with the pink/orange pigment on snout of juvenile; inside of lower lip with small blotch of yellow pigment in adults, inside of upper lip with stripe of yellow (adults) or orange (juvenile); photographic angle did not permit characterization of pigment on inside of lower lip of juvenile; lower jaw and lower two thirds of head white, with pinkish cast in holotype; in adults, dorsal fin with yellow spines and mostly white inter-spinous membranes; soft dorsal-fin rays yellow, membrane between anterior rays yellow, and membrane between rays of remainder of fin with small to large pale area centrally, size of pale area increasing posteriorly such that membrane between posteriormost rays completely pale; some rays and membranes in posterior portion of soft dorsal fin with pale rose pigment in smaller adult; a thin white margin extending along outer edge of entire dorsal fin, this margin appearing blue-white when fish photographed against black background (Fig. 3); in juvenile, inter-spinous membranes of dorsal fin mostly pale and soft dorsal mostly pale except for yellow stripe at the base and yellow stripe near outer margin of fin; caudal fin mostly yellow in holotype, central portion of fin with pale outer margin and with pale to pinkish-orange membranes between rays; thin pinkish-orange stripe present along dorsal and ventral margins of fin; distal tip of lower lobe with reddish-black blotch, a few thin streaks of black extending proximally from this blotch; pigment on caudal fin of smaller adult similar but with less pinkish-orange pigment, and caudal fin of juvenile mostly clear with a large, oval-shaped, oblique yellow blotch on outer half of both upper and lower 


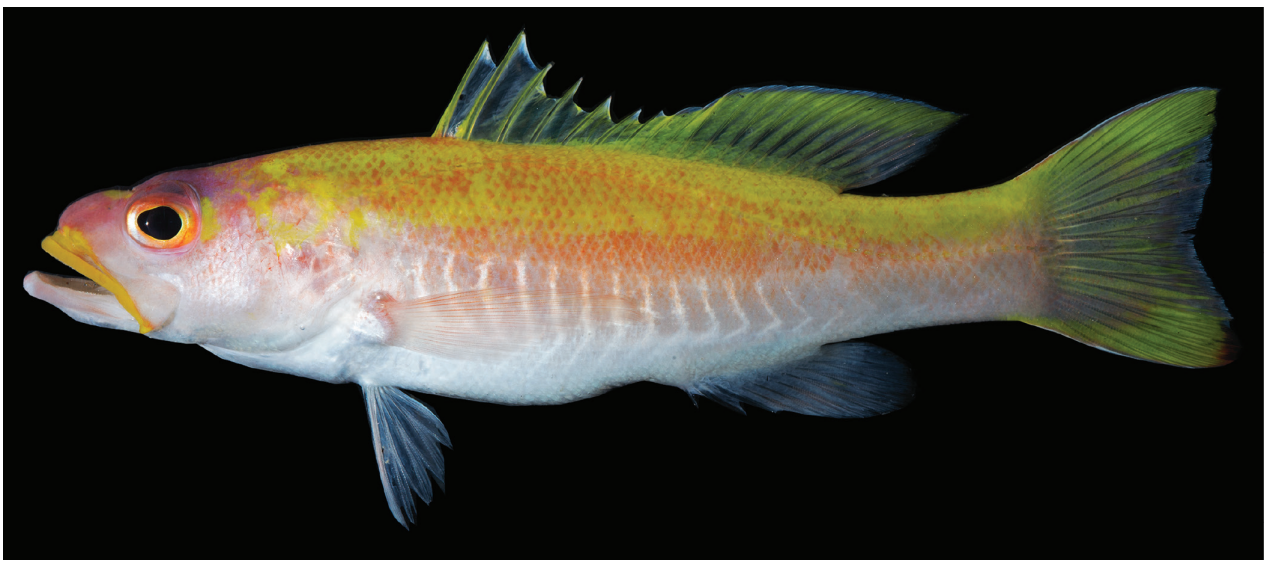

Figure 3. Liopropoma santi sp. n., USNM 426811, holotype, 116 mm SL (photographed against a black background).

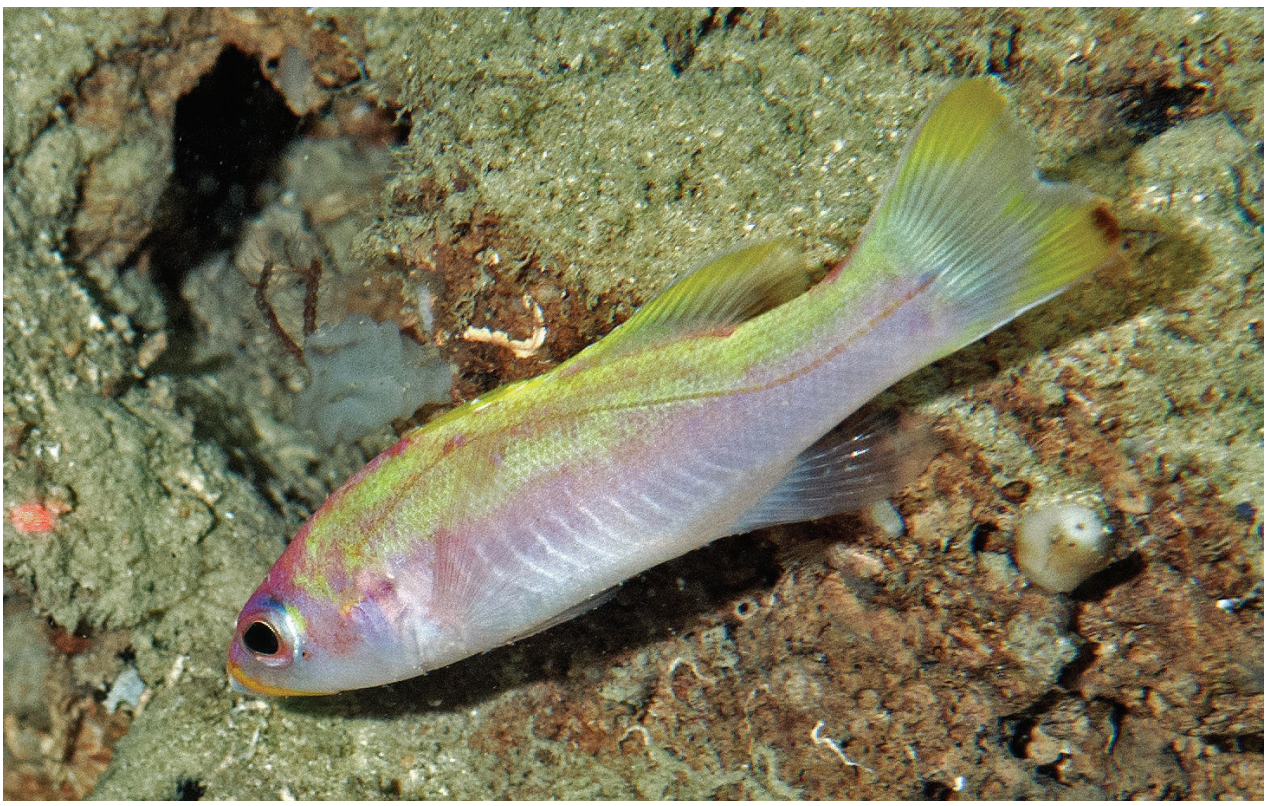

Figure 4. In-situ photograph of Liopropoma santi sp. n., taken from the Curasub submersible at $204 \mathrm{~m}$ on a reef slope off Jan Theil Bay, Curaçao, 5 Nov 2013. Photo courtesy of Substation Curaçao.

lobes; dark spot on distal portion of ventral caudal lobe relatively larger in juvenile; anal fin white, with faint pinkish-yellow streak on first through fifth rays in holotype, little or no color in smaller adult and juvenile; pelvic fin white; pectoral fin translucent with pale pinkish-orange cast; general coloration most intense in the holotype and least intense in the juvenile.

In alcohol (see Fig. 6A), body pale, the only pigment a dark blotch on distal tip of ventral caudal-fin lobe. 
Distribution. Known only from Curaçao, southern Caribbean.

Habitat. Off Curaçao, L. santi is found from 182-241 m inhabiting rocky slopes and ledges. It retreats into small caves and crevices when approached and illuminated by the submersible. Figure 4 shows an in-situ photograph taken from the Curasub submersible at $204 \mathrm{~m}$ on a reef slope off Jan Theil Bay, Curaçao.

Etymology. The specific name honors Roger Sant, who participated in the Curasub submersible dive at Playa Forti during which the USNM 426813 paratype was collected. Roger and Victoria Sant have provided generous funding to the Smithsonian Institution's National Museum of Natural History for ocean-related activities.

Common name. "Spot-tail golden bass" is in reference to the dark spot on the lower lobe of the caudal fin, which, along with other characters, distinguishes L. santi from the two other species of western Atlantic Liopropoma that have predominantly golden coloration, L. aberrans and L. olneyi.

Comparisons. Counts and measurements of the three western Atlantic "golden basses" collected off Curaçao, L. santi, L. aberrans, and L. olneyi, are given in Table 2, representative images of the three are provided in Figure 5, and a summary of major differences among them appears in Table 3. An image of a freshly collected specimen of a species of the related genus Bathyanthias is also included in Figure 5 for comparative purposes. Liopropoma santi is easily distinguished from the others by color in life, especially by the presence of a yellow or orange stripe externally on the upper lip, a series of white chevron-shaped markings on the ventral portion of the trunk, and the reddish-black blotch on the distal portion of the lower caudal-fin lobe. The last also visually distinguishes $L$. santi from $L$. aberrans and L. olneyi in preservative. Liopropoma santi is further distinguished from both of those species by having more dorsal-fin rays, more gill rakers on the first arch, and usually a larger eye (Table 2). From L. aberrans, L. santi is further distinguished by having more pectoral-fin rays, a narrower body at the dorsal-fin origin, a narrower caudal peduncle, longer fourth-sixth dorsal-fin spines, and a more shallow indentation in the spinous dorsal fin (Tables 2, 3).

Baldwin and Johnson (2014) discussed the status of L. aberrans, which was described from a single specimen collected off Cuba in the $19^{\text {th }}$ century (Poey 1860) and redescribed from a single specimen collected off the Bahamas in the $20^{\text {th }}$ century (Robins 1967). They noted differences in the descriptions of color patterns of the two specimens and numbers of dorsal-fin rays (IX, 12 in Poey's L. aberrans, VIII, 12 in Robins' L. aberrans), and they questioned whether or not the two specimens represent the same species. Specimens of L. aberrans collected off Curaçao ("Curaçao L. aberrans") share with the Bahamas L. aberrans the same dorsal-fin count, general body shape, and color pattern, although Baldwin and Johnson (2014) noted some differences in the color pattern. Curaçao L. aberrans have 17-18 gill rakers on the first arch (Table 2), whereas Robins (1967) reported 14 for the Bahamas specimen; however, as noted by Baldwin and Johnson (2014), Robins' count only included the rudimentary pads on the upper limb. Examination of the Robins' Bahamas specimen (UMML 22324) indicates that there are four rudimentary pads on the lower limb, and thus the total number of gill rakers on the first arch is 18 . 
Table 2. Selected counts and measurements for the type series of Liopropoma santi sp. n., L. aberrans from Curaçao, and $L$. olneyi. Measurements are in percentages of SL. Data for $L$. aberrans are from Curaçao specimens examined in this study, those for L. olneyi are from Baldwin and Johnson (2014).

\begin{tabular}{l|c|c|c|c|c}
\hline & L. santi & L. santi & L. santi & L. olneyi & L.aberrans \\
\hline $\begin{array}{l}\text { Museum Catalog } \\
\text { Numbers }\end{array}$ & $\begin{array}{c}\text { USNM 426811 } \\
\text { Holotype }\end{array}$ & $\begin{array}{c}\text { USNM 426813 } \\
\text { Paratype }\end{array}$ & $\begin{array}{c}\text { USNM 414824 } \\
\text { Paratype }\end{array}$ & See Appendix & See Appendix \\
\hline SL (mm) & 116 & 76.2 & 42.0 & $53.2-84.3$ & $64.8-116$ \\
\hline Dorsal Fin & 15 & 15 & 15 & $14-15$ & 14 \\
\hline Pectoral Fin & $6+14=20$ & $6+14=20$ & $6+15=21$ & $5-6+12-13=17-19$ & $5-6+11-13=17-18$ \\
\hline $\begin{array}{l}\text { Gill Rakers on First } \\
\text { Arch }\end{array}$ & 9.4 & 10 & 12 & $7.8-9.4$ & $7.4-8.7$ \\
\hline $\begin{array}{l}\text { Orbit diameter } \\
\begin{array}{l}\text { Body depth at dorsal- } \\
\text { fin origin }\end{array}\end{array}$ & 26 & 25 & 23 & $20-24$ & $27-29$ \\
\hline $\begin{array}{l}\text { Least depth of caudal } \\
\text { peduncle }\end{array}$ & 13 & 13 & 11 & $13-15$ & $16-17$ \\
\hline $\begin{array}{l}\text { Length of dorsal-fin } \\
\text { spine IV }\end{array}$ & 11 & 11 & 12 & $9.7-12$ & $8.1-9.7$ \\
\hline $\begin{array}{l}\text { Length of dorsal-fin } \\
\text { spine V }\end{array}$ & 9.5 & 10 & 6.9 & $8.3-9.3$ & $3.7-5.6$ \\
\hline $\begin{array}{l}\text { Length of dorsal-fin } \\
\text { spine VI }\end{array}$ & 8.2 & 7.9 & 6.9 & $7.3-8.9$ & $3.6-5.6$ \\
\hline
\end{tabular}

Table 3. Summary of differences in morphology and depth ranges among the three golden-colored Liopropoma species off Curaçao.

\begin{tabular}{|c|c|c|c|}
\hline Character & L. santi sp. $\mathrm{n}$. & L. olneyi & L. aberrans \\
\hline Relative body depth & Shallow (23-26\% SL) & Shallow (20-24\% SL) & Deeper (27-29\% SL) \\
\hline Dorsal fin indentation & Moderate $\left(6^{\text {th }}\right.$ spine $7-8 \%$ SL) & Weak (6 $6^{\text {th }}$ spine $7-9 \%$ SL) & Strong $\left(6^{\text {th }}\right.$ spine $\left.4-6 \% \mathrm{SL}\right)$ \\
\hline Dorsal-fin rays & VIII, 13 & IX, 11 & VIII, 12 \\
\hline Gill rakers on first arch & $20-21$ & $17-19$ & $17-18$ \\
\hline Orbit diameter (\% SL) & $9.4-12$ & $7.8-9.4$ & $7.4-8.7$ \\
\hline White flank chevrons & yes & no & no \\
\hline Body ground colors & yellow over white & yellow over white & yellow over orange \\
\hline Yellow stripe through eye & no & yes & yes \\
\hline Yellow-orange upper lip & yes & no & no \\
\hline Yellow spots on body & no & adult $\&$ juvenile & juvenile only \\
\hline $\begin{array}{l}\text { Dark spot on lower } \\
\text { caudal-fin lobe }\end{array}$ & yes & no & no \\
\hline Depth range $(\mathrm{m})$ & $181-241$ & $133-193$ & $98-149$ \\
\hline
\end{tabular}

Curaçao and Bahamas L. aberrans, however, appear to have different depth preferences, with Robins' L. aberrans occurring deeper-229 m. At Curaçao, L. aberrans was collected between 98 and149 m and observed by us only within that depth range during nearly 100 submersible dives over a three-year period. This is unlikely to be due to effects of differences in habitat availability at the two locations, as $L$. santi and $L$. olneyi occur at deeper depths than L. aberrans at Curaçao. 

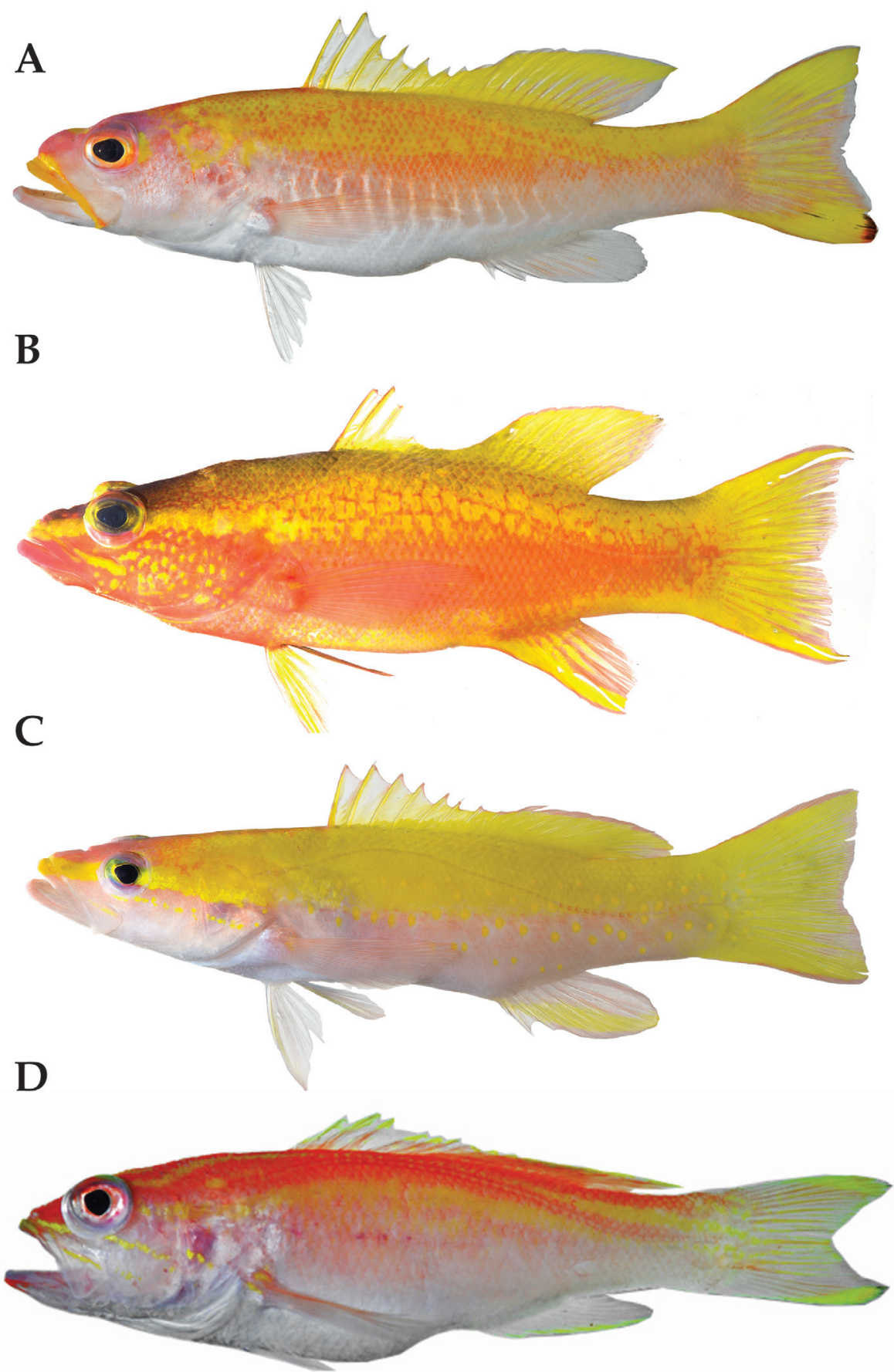

Figure 5. Comparison of the three species of "golden basses" off Curaçao and Bathyanthias sp. from Panama: A Liopropoma santi sp. n., USNM 426811, holotype, 116 mm SL, DNA \#CUR 13280 B L. aberrans, USNM 426807, 102 mm SL, DNA \#CUR 12226 C L. olneyi, USNM 426805, holotype, 84.3 mm SL, DNA \#CUR 13200 D Bathyanthias sp., USNM 407791, 110 mm SL, DNA \#MOC 11791. 

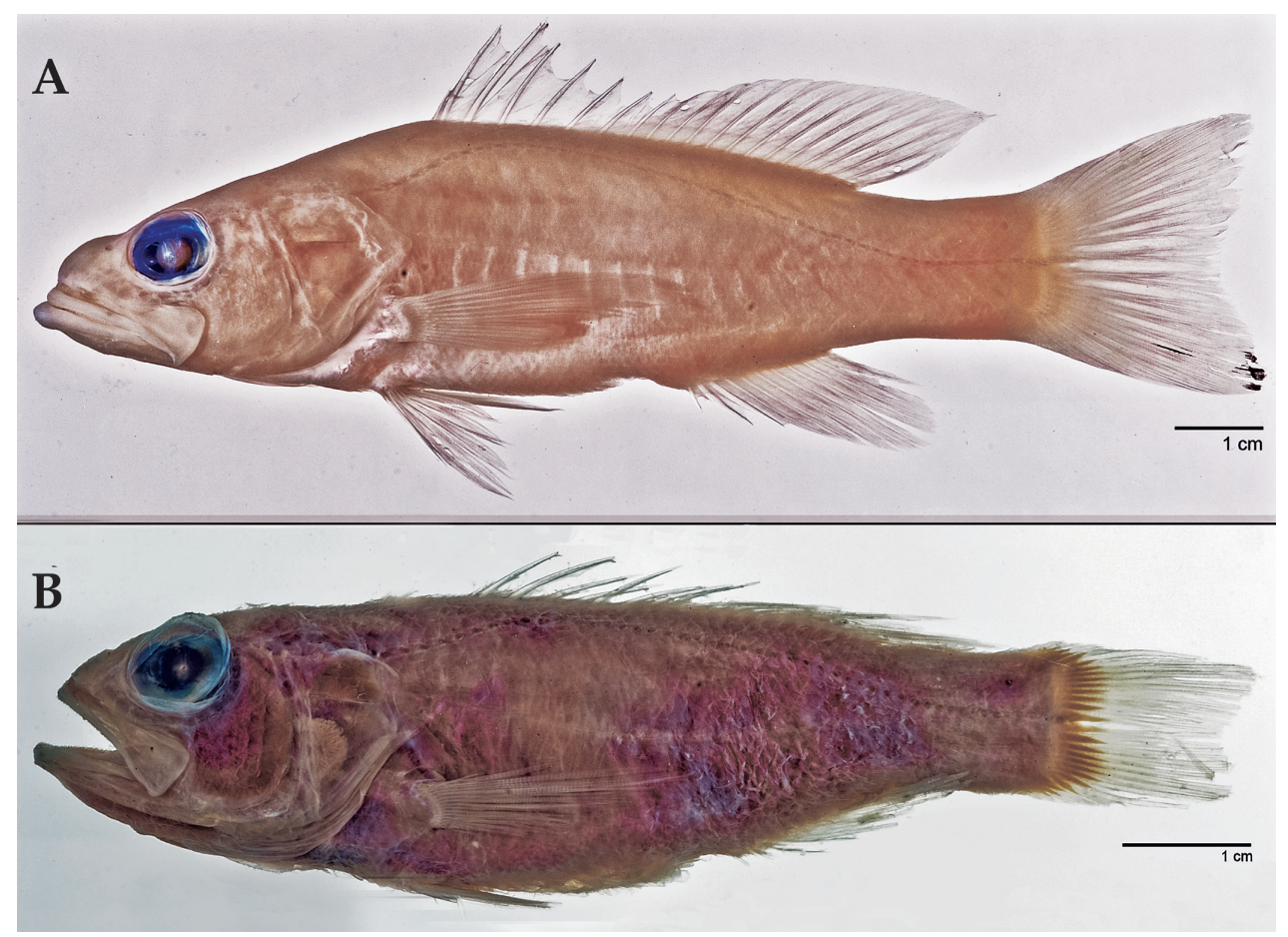

Figure 6. Comparison of Liopropoma and Bathyanthias: A L. santi sp. n., USNM 426811, holotype, 116 mm SL (photographed after preservation) B B. cubensis (Schultz 1958), USNM 158138, holotype, 80.3 mm SL. Photos by Sandra Raredon.

Poey (1860) did not provide depth data or a gill-raker count for his $115-\mathrm{mm}$ SL specimen from Cuba. Curaçao L. aberrans differs from the Cuban L. aberrans in dorsal-fin count and certain aspects of color pattern, but fish from those two sites share the presence of yellow spots on the cheek (sometimes lacking in juvenile Curaçao L. aberrans), spots that were not mentioned by Robins (1967) for the 112-mm SL Bahamas $L$. aberrans. The whereabouts of the holotype of $L$. aberrans are unknown (Eschmeyer 2013), and, in the absence of additional material from the type locality for comparative purposes, we follow Baldwin and Johnson (2014) in tentatively recognizing the specimens from Cuba, Bahamas, and Curaçao as L. aberrans. As noted by Baldwin and Johnson (2014), a digitized copy of a color photograph of a specimen of L. aberrans from Jamaica taken and provided by Patrick Colin shows a color pattern nearly identical to that of Curaçao L. aberrans. Should Poey's L. aberrans prove to be distinct from specimens from the Bahamas, Curaçao, and Jamaica, one or more new species will need to be recognized.

Liopropoma santi differs from Poey's and Robins' L. aberrans in number of dorsal-fin rays (VIII, 13 vs. IX, 12 and VIII, 12, respectively) and shape of dorsal fin (with only a moderate indentation in spinous dorsal fin in $L$. santi, deep indentation in the others). It further differs from Robins' $L$. aberrans in numbers of pectoral-fin 
Table 4. Dorsal-fin counts of western Atlantic Liopropomini fishes. Data for Bathyanthias atlanticus, $B$. cubensis, and B. mexicanus are from Schultz (1958); for Liopropoma aberrans (Cuba) Poey (1860); for L. aberrans (Bahamas) Robins (1967); for L. carmabi, L. eukrines, L. mowbrayi, L. rubre Randall (1963); and for L. olneyi Baldwin and Johnson (2014).

\begin{tabular}{|c|c|c|c|c|c|c|c|}
\hline & \multicolumn{2}{|c|}{ SPINES } & \multicolumn{5}{|c|}{ SOFT RAYS } \\
\hline & VIII & IX & 11 & 12 & 13 & 14 & 15 \\
\hline Bathyanthias atlanticus & + & & & & & + & \\
\hline Bathyanthias cubensis & + & & & & + & & \\
\hline Bathyanthias mexicanus & + & & & & & + & + \\
\hline Bathyanthias roseus $^{l}$ & + & & & & & + & \\
\hline Liopropoma aberrans (Curaçao) & + & & & + & & & \\
\hline Liopropoma aberrans (Cuba) & & + & & + & & & \\
\hline Liopropoma aberrans (Bahamas) & + & & & + & & & \\
\hline Liopropoma carmabi & + & & & + & + & & \\
\hline Liopropoma eukrines & + & & & + & & & \\
\hline Liopropoma mowbrayi & + & & & + & & & \\
\hline Liopropoma olneyi & & + & + & & & & \\
\hline Liopropoma rubre & + & & & + & & & \\
\hline Liopropoma santi sp. $\mathrm{n}$. & + & & & & + & & \\
\hline
\end{tabular}

${ }^{1}$ As noted by Baldwin and Johnson (1993), Günther (1880) gave IX, 14 as the dorsal-fin count for $B$. roseus, but their examination of a radiograph of the type specimen indicates that it has VIII dorsal spines.

rays (15 vs. 14) and gill rakers on the first arch (20-21 vs. 17-18), and color pattern (presence of diagnostic color features of $L$. santi-see Diagnosis-vs. absence). From other western Atlantic Liopropoma (L. carmabi [Randall 1963], L. eukrines [Starck and Courtenay 1962], L. mowbrayi [Woods and Kanazawa 1951], L. rubre Poey 1861), L. santi differs most notably in color pattern (Fig. 1) and in having VIII, 13 dorsal-fin rays (vs. VIII, 12 in all except one specimen of L. carmabi with VIII, 13-Table 4).

Counts of L. santi closely match those of Bathyanthias cubensis (Schultz, 1958) in having VIII, 13 dorsal-fin rays; III, 8 anal-fin rays; 15 pectoral-fin rays; and 20-21 gill rakers on the first arch. Liopropoma santi has 47-49 lateral-line scales, whereas $B$. cubensis has 46-47. The two species are otherwise very different. Liopropoma santi has a shallower trunk (body depth 23-26\% SL and caudal-peduncle depth 11-13\% SL in $L$. santi vs. 28-32\% SL and 14-15\% SL, respectively, in B. cubensis - Schultz, 1958), and $L$. santi has a single blotch of dark pigment on the distal portion of the lower caudalfin lobe vs. dark pigment on the distal ends of all caudal-fin rays. Like other species of Bathyanthias, the dorsal profile of the head in B. cubensis is convex (vs. usually straight in Liopropoma - although there may be a bump on the snout and the profile may be slightly convex in large specimens of Liopropoma); there is little indentation in the margin of the spinous dorsal fin (vs. larger indentation); the posteroventral corner of the maxilla has a weakly developed hook-like process (vs. well developed in Liopropoma - see Randall and Taylor [1988] and Baldwin and Johnson [1993]); and in Bathyanthias, the anterior portion of the lateral line is broadly curved over the pectoral fin (vs. 
sharply curved in Liopropoma). Differences between $L$. santi and $L$. cubensis can be seen in Figure 6, and the generic characters listed above can be seen in Figures 5 and 6 . The depth range of $B$. cubensis is greater than that of L. santi, 183-411 m vs. $182-241 \mathrm{~m}$.

\section{Discussion and conclusions}

A combination of morphological and genetic differences supports the recognition of L. santi as a valid new species of Liopropoma. Liopropoma santi inhabits depths of 182$241 \mathrm{~m}$ off Curaçao, making it the deepest known Liopropoma species in the western Atlantic (Fig. 7). The shallower portion of its depth range overlaps the deeper portion of the depth range of L. olneyi (133-193 m), but with the exception of Robins' (1967) specimen of $L$. aberrans from the Bahamas $(229 \mathrm{~m})$, no other western Atlantic Liopropoma species occur within the depth range of $L$. santi. A preliminary phylogeny of western Atlantic Liopropoma based on parsimony analysis of the COI data is shown in Figure 8. In that phylogeny, the three species that inhabit depths of 3-135 $\mathrm{m}$ (L. rubre, $L$. carmabi, and $L$. mowbrayi) form a monophyletic group that is sister to a clade comprising two species that inhabit depths of 30-150 m (L. eukrines and L. aberrans from Curaçao). Those clades combined are sister to a clade comprising the deepest western Atlantic Liopropoma (L. olneyi and L. santi, 133-241 m) plus two species of the genus Bathyanthias (B. mexicanus [Schultz 1958] and a putative new species from Panama) that were collected at 143-259 m. Two additional species of Bathyanthias, B. atlanticus [Schultz, 1958] and B. cubensis (not available for inclusion in the molecular phylogenetic analysis), are known from $82-411 \mathrm{~m}$, and the depth range of non-Curacao $L$. aberrans (also not available for inclusion in the phylogenetic analysis) is $89-230 \mathrm{~m}$ (Robins 1967, Ocean Biogeographic Information System [OBIS] - http://www.iobis. org/, Fishnet 2 - http://www.fishnet2.net/).

The COI data provide excellent support for the monophyly of species of western Atlantic Liopropoma but poor support for clades within the genus (see bootstrap values in Fig. 8). Nevertheless, the strict consensus (Fig. 8) suggests that western Atlantic liopropomins are monophyletic with respect to Indo-Pacific Liopropoma (L. lunulatum, L. tonstrinum, and L. pallidum in Fig. 8). A more robust phylogenetic hypothesis is needed that is derived from additional genes and more Indo-Pacific species of Liopropoma, but the COI data suggest a relationship between depth and monophyletic clades in western Atlantic Liopropomini that warrants further investigation. Members of the three clades of western Atlantic liopropomins identified in the phylogeny show a tendency to occupy different depth strata $(3-135 \mathrm{~m}, 30-150 \mathrm{~m}$, and $82-411 \mathrm{~m}$ ). Based on our few specimens, it appears that $L$. santi has larger eyes than its sister species, $L$. olneyi (Table 3 ), which may represent an adaptation allowing $L$. santi to extend its range to greater depths. Among the three golden basses at Curaçao ( $L$. aberrans, $L$. olneyi, L. santi), L. aberrans has the shallowest range and shows a tendency to have the smallest eyes (Table 3). Adaptation to life at different depths may have been involved in the speciation of this co-occuring species group. It may also be involved in the di- 


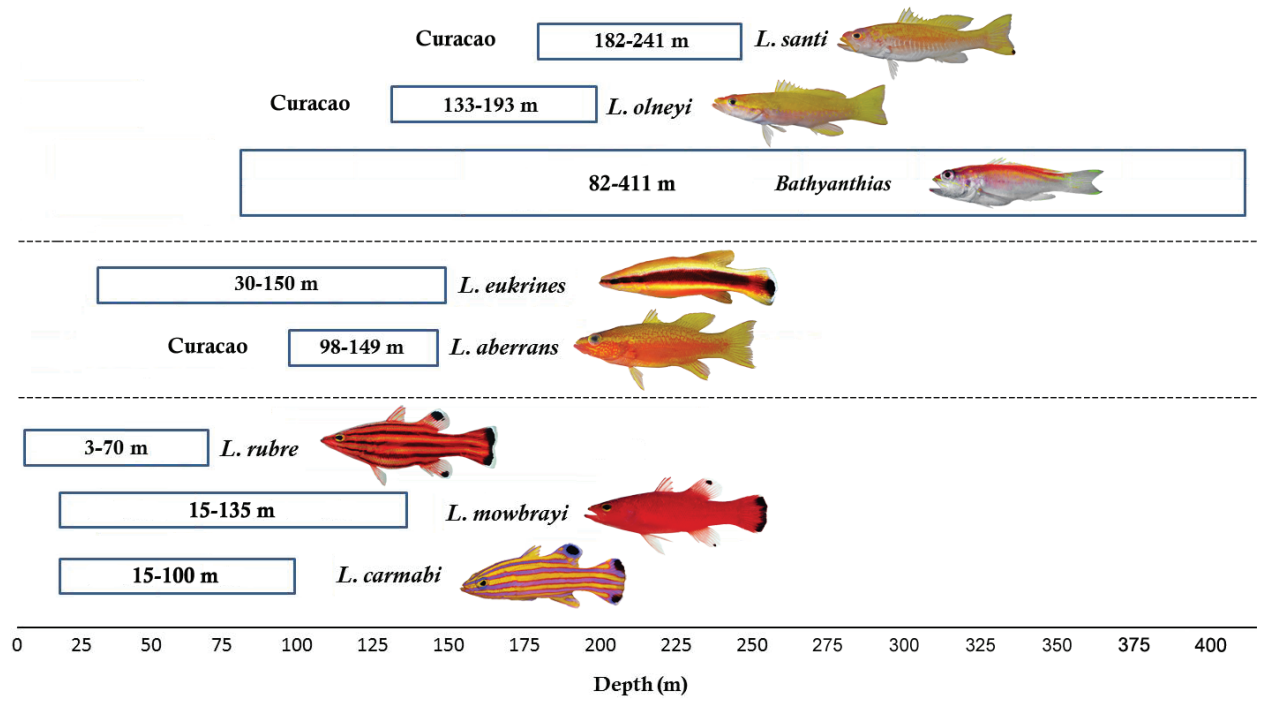

Figure 7. Depth distributions of western Atlantic Liopropoma and Bathyanthias species that were included in the phylogenetic analysis (see Fig. 8). Photographs of L. rubre and L. mowbrayi by James Van Tassell and Ross Robertson.

vergence between $L$. mowbrayi and $L$. rubre, which represent sister species that show only partial overlap in their depth ranges (Fig. 7) but broadly overlapping geographic ranges that incorporate most of the Caribbean and adjacent areas. Adaptation to use of different depth strata may also have been involved in the initial diversification of western Atlantic liopropomins into three clades that now occupy the same geographic area. Such parapatric ecological speciation, in which species diverge along environmental gradients, has been proposed for other marine fishes including Halichoeres (Rocha et al. 2005) and Sebastes (Ingram 2011). In Sebastes, Ingram (2011) found a strong signal of speciational evolution in depth habitats and in traits apparently related to life at different depths, such as eye size.

Conversely, the sister species $L$. eukrines and L. aberrans overlap substantially in depth range but show a significant amount of geographic separation: L. eukrines is largely restricted to the Gulf of Mexico and southeastern USA, whereas L. aberrans is primarily Caribbean. However, there is one inconsistency in this pattern of either geographic or depth segregation among members of the same clade: L. carmabi and both species in its sister group, L. rubre and L. mowbrayi, have both geographic- and depth ranges that broadly overlap. Liopropomins have pelagic larvae, and allopatric speciation might be facilitated by larval dispersal to new areas. Possibly both ecological and allopatric speciation have occurred in the group, but, if so, more information on depth and geographic distributions, morphological traits associated with life at different depths, and evolutionary relationships is needed to estimate their relative roles. Depth and morphological information for the three members of the L. rubre clade collected at the same geographic location would be highly relevant in this regard. At 


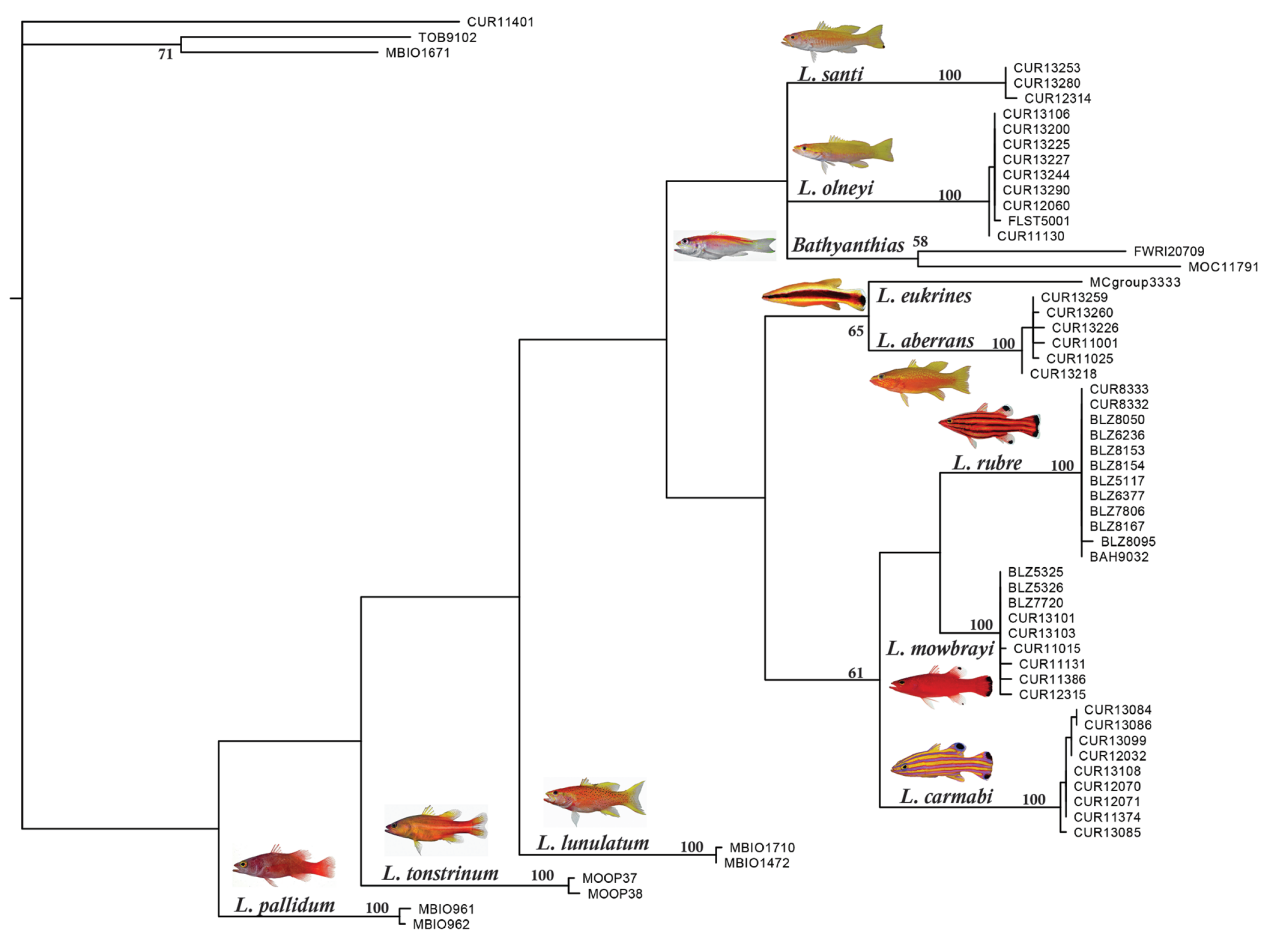

Figure 8. The strict consensus of a maximum parsimony analysis of the COI region among western Atlantic Liopropoma and related taxa. The tree was rooted on Scorpaena plumieri, (CUR11401), and the non-liopropomin serranids Rypticus carpenteri (TOB9102) and Grammistes sexlineatus (MBIO1671) were included as additional outgroups. Photographs of $L$. rubre and L. mowbrayi by James Van Tassell and Ross Robertson; photos of L. pallidum and L. lunulatum by Jeffrey Williams (from Encyclopedia of Life); photo of L. tonstrinum by Richard Winterbottom (from Encyclopedia of Life).

Puerto Rico all three species in that clade occur on the same mesophotic reefs, where they reach the same maximum depth (Bejarano et al 2014). At Curaçao Adriaan Schrier, who operates Substation Curaçao, has been actively collecting all three species for many years using a combination of traditional SCUBA, mixed gas SCUBA, and the Curasub. He provided (personal communication March 2014) the following information for that location: L. rubre occurs at $12-55 \mathrm{~m}, L$. mowbrayi at $12-135 \mathrm{~m}$, and $L$. carmabi at $25-100 \mathrm{~m}$. He also noted that while L. mowbrayi and L. carmabi are found in areas with small-scale coral and rock shelter and rubble, $L$. rubre is restricted to caves in large scale coral structures and is much more secretive than the other two species. These observations indicate that members of the L. rubre clade show some degree of depth segregation within a site, as well as microhabitat segregation.

The phylogeny (Fig. 8) further suggests the need to reanalyze generic relationships within the Liopropomini, as Bathyanthias is embedded within western Atlantic Liopropoma. Morphologically, L. santi, L. olneyi, and Bathyanthias differ from other western 
Atlantic Liopropoma in having a smaller indentation in the margin of the dorsal fin, and those liopropomins lack body stripes and have similar pale orange/yellow/rose coloration. Four species of Bathyanthias have been described - B. atlanticus (Schultz, 1860), B. cubensis (Schultz, 1860), B. mexicanus (Schultz, 1860), and B. roseus Günther 1880. Of those, only B. mexicanus from the Gulf of Mexico (FWRI 20709) was available for inclusion in our phylogenetic analysis. The other Bathyanthias species included, which may represent an undescribed species, is from Central America - Panama (USNM 407791, MOC 11791). Its combination of dorsal-, pectoral, lateral-line, and gill-raker counts do not match any other known species of Bathyanthias.

Of the three western Atlantic species of Liopropoma with depth distributions entirely below depths accessible using conventional scuba gear - L. aberrans, L. olneyi, and L. santi - two have been discovered only recently through submersible diving to $300 \mathrm{~m}$ off Curaçao in the southern Caribbean (L. olneyi and L. santi). More exploration of western Atlantic tropical mesophotic and other deep-reef depths is needed to fully document fish diversity even in well-studied taxonomic groups such as the Serranidae.

\section{Comparative material}

Specimens, color images, or both, were examined of all western Atlantic liopropomin material listed in the Appendix. The following non-Curaçao L. aberrans material was examined: UF 222324, 1 specimen, Bahamas; UF 230721, 1, Jamaica; UF 230254, 1, French Guiana.

\section{Acknowledgments}

For contributing in various ways to this project, we thank the following (in alphabetical order): Bruce Brandt, Barry Brown, Cristina Castillo, Patrick Colin, Matthew Craig, Tico Christiaan, Dave Johnson, Rob Loendersloot, Dan Mulcahy, Diane Pitassy, Sandra Raredon, Rob Robins, Laureen Schenk, Adriaan Schrier, Ian SilverGorges, Raymond Simpson, Jennifer Strotman, Laura Tancredi, Barbara van Bebber, Lee Weigt. Victor Springer provided helpful comments on a draft of the manuscript. Funding for the Smithsonian Institution's Deep Reef Observation Project was provided internally by the Consortium for Understanding and Sustaining a Biodiverse Planet to $\mathrm{CCB}$, the Competitive Grants for the Promotion of Science program to CCB and DRR, the Herbert R. and Evelyn Axelrod Endowment Fund for systematic ichthyology to CCB, and externally by National Geographic Society's Committee for Research and Exploration to CCB (Grant \#9102-12). This is Ocean Heritage Foundation/ Curacao Sea Aquarium/Substation Curacao (OHF/SCA/SC) contribution number 4. 


\section{References}

Baldwin CC, Johnson GD (2014) Connectivity across the Caribbean Sea: DNA barcoding and morphology unite an enigmatic fish larva from the Florida Straits with a new species of sea bass from deep reefs off Curaçao. PLoS ONE 9(5): e97661. doi: 10.1371/journal. pone.0097661

Baldwin CC, Johnson GD (1993) Phylogeny of the Epinephelinae (Teleostei: Serranidae). Bulletin of Marine Science 22: 240-283.

Baldwin CC, Weigt LA (2012) A new species of soapfish (Teleostei: Serranidae: Rypticus), with redescription of $R$. subbifrenatus and comments on the use of DNA barcoding in systematic studies. Copeia 2012: 23-36. doi: 10.1643/CG-11-035

Baldwin CC, Robertson DR (2013) A new Haptoclinus blenny (Teleostei, Labrisomidae) from deep reefs off Curacao, southern Caribbean, with comments on relationships of the genus. ZooKeys 306: 71-81. doi: 10.3897/zookeys.306.5198

Bejarano L, Appeldorn RS, Nemeth M (2014) Fishes associated with mesophotic coral ecosystems at La Parguera, Puerto Rico. Coral Reefs. doi: 10.1007/s00338-014-1125-6

Betancur-R R, Broughton RE, Wiley EO, Carpenter K, López JA, Li C, Holcroft NI, Arcila D, Sanciangco M, Cureton JC II, Zhang F, Buser T, Campbell MA, Ballesteros JA, RoaVaron A, Willis S, Borden WC, Rowley T, Reneau PC, Hough DJ, Lu G, Grande T, Arratia G, Ortí G (2013) The tree of life and a new classification of bony fishes. PLoS Currents Tree of Life. 2013 April 18. doi: 10.1371/currents.tol.53ba26640df0ccaee75b b165c8c26288

Chakrabarty P, Warren M, Page LM, Baldwin CC (2013) GenSeq: An updated nomenclature and ranking for genetic sequences from type and non-type sources. Zookeys 346: 29-41.

Eschmeyer WN (Ed) (2013) Catalog of fishes: genera, species, references. http://research.calacademy.org/research/ichthyology/catalog/fishcatmain.asp [Accessed 10 Dec 2013]

Günther A (1880) Report on the shore fishes procured during the voyage of H. M. S. Challenger in the years 1873-1876. In: Report on the scientific results of the voyage of H.M.S. Challenger during the years 1873-76. Zoology. v. 1 (pt 6): 1-82, Pls. 1-32.

Hubbs CL, Lagler KF (1958) Fishes of the Great Lakes region. University of Michigan Press. Ann, Arbor, Michigan, 213 pp.

Ingram T (2011) Speciation along a depth gradient in a marine adaptive radiation. Proceedings of the Royal Society B 278: 613-618.

Johnson GD (1983) Niphon spinosus: a primitive epinepheline serranid, with comments on the monophyly and interrelationships of the Serranidae. Copeia: 777-787.

Kimura M (1980) A simple method for estimating evolutionary rates of base substitutions through comparative studies of nucleotide sequences. Journal of Molecular Evolution 16: 111-120.

Near TJ, Dornburg A, Eytan RI, Keck BP, Smith WL, Kuhn KL, Moore JA, Price SA, Burbrink FT, Friedman M, Wainwright PC (2013) Phylogeny and tempo of diversification in the superradiation of spiny-rayed fishes. Proceedings of the National Academies of Science 110: 12738-12743. doi: 10.1073/pnas.1304661110

Poey Y (1860) Poissons de Cuba, espèces nouvelles. Memorias Sobre la Historia Natural de la Islad de Cuba 2: 115-335. 
Poey Y (1861) Memorias sobra la historia natural de la Isla de Cuba, acompañadas de sumarios Latinos y extractos en Francés. Tomo 2. La Habana 2: 1-96 (1858), 97-336 (1860), 337-442 (1861), Pls. 1-19.

Randall JE (1963) Three new species and six new records of small serranoid fishes from Curaçao and Puerto Rico. Studies of the Fauna of Curacao and other Caribbean Islands 19: 77-110.

Randall JE, Taylor L (1988) Review of the Indo-Pacific fishes of the serranid genus Liopropoma, with descriptions of seven new species. Indo-Pacific Fishes 16: 1-47.

Robins CR (1967) The status of the serranid fish Liopropoma aberrans, with the description of a new, apparently related genus. Copeia 1967: 591-595. doi: 10.2307/1442237

Rocha LA, Robertson DR, Roman J, Bowen BW (2005) Ecological speciation in tropical reef fishes. Proceedings of the Royal Society B 272: 573-579. doi: 10.1098/2004.3005

Sabaj Pérez MH (Ed) (2012) Standard symbolic codes for institutional resource collections in herpetology and ichthyology: an Online Reference. Version 3.0. American Society of Ichthyologists and Herpetologists, Washington, DC. http://www.asih.org/ [accessed on 23 February 2012]

Saitou N, Nei M (1987) The neighbor-joining method: a new method for reconstructing phylogenetic trees. Molecular Biological Evolution 14: 406-425.

Schultz LP (1958) Three new serranid fishes, genus Pikea, from the western Atlantic. Proceedings of the United States National Museum 108: 321-329. doi: 10.5479/si.00963801.108-3405.321

Seutin G, Bagley P, White BN (1991) Preservation of avian blood and tissue samples for DNA analyses. Canadian Journal of Zoology 69: 82-90. doi: 10.1139/z91-013

Smith WL, Craig MT (2007) Casting the percomorph net widely: The importance of broad taxonomic sampling in the search for the placement of serranid and percid fishes. Copeia: 35-55. doi: 10.1643/0045-8511(2007)7[35:CTPNWT]2.0.CO;2

Stark WA II, Courtenay WR Jr. (1962) Chorististium eukrines, a new serranid fish from Florida, with notes on related species. Proceedings of the Biological Society of Washington 75: 159-167.

Swofford D (2002) PAUP*: phylogenetic analysis using parsimony (*and other methods). Sinauer Associates, Sunderland, Massachusetts.

Thunberg CP (1792) Åtskillige förut okánde Fiskar af abborslágtet. Kongliga Vetenskaps Akademiens nya Handlingar, Stockholm v. 13 (for 1792): 141-143, Pl. 5.

Weigt LA, Driskell AC, Baldwin CC, Ormos A (2012) DNA Barcoding Fishes. In: Kress WJ, Erickson DL (Eds) DNA Barcodes: Methods and Protocols. Methods in Molecular Biology 858: 109-126.

Woods LP, Kanazawa RH (1951) New species and new records of fishes from Bermuda. Fieldiana Zoology 31: 629-644. 


\section{Appendix}

Links between DNA voucher specimens, GenBank accession numbers, and cytochrome c oxidase subunit I (COI) sequences of Liopropoma santi sp. nov., related Liopropomini, and outgroup taxa.

\begin{tabular}{|c|c|c|}
\hline Catalog Number/DNA Number & GenBank No. & GenSeq Designation \\
\hline \multicolumn{3}{|l|}{ Liopropoma santi sp. $\mathrm{n}$. } \\
\hline USNM 426811, CUR 13253, Holotype & KJ526147 & Geneseq-1 COI \\
\hline USNM 426813, CUR 13280, Paratype & KJ526148 & genseq-2 COI \\
\hline USNM 414824, CUR 12314, Paratype & KJ526146 & genseq-2 COI \\
\hline \multicolumn{3}{|l|}{ Liopropoma olneyi } \\
\hline USNM 426805, CUR 13200, Holotype & KF770874 & genseq-1 COI \\
\hline USNM 406130, CUR 11130, Paratype & KF770856 & genseq-2 COI \\
\hline USNM 414828, CUR 12060, Paratype & KF770862 & genseq-2 COI \\
\hline USNM 426808, CUR 13225, Paratype & KF770876 & genseq-2 COI \\
\hline USNM 426809, CUR 13227, Paratype & KF770878 & genseq-2 COI \\
\hline USNM 426810, CUR 13244, Paratype & KF770879 & genseq-2 COI \\
\hline USNM 426815, CUR 13290, Paratype & KF770882 & genseq-2 COI \\
\hline USNM 422698, CUR13106, Paratype & KF770872 & genseq-2 COI \\
\hline USNM 426868, FLST 5001, Paratype (larva) & KF770883 & \\
\hline \multicolumn{3}{|l|}{ Liopropoma aberrans } \\
\hline USNM 406001, CUR 11001 & KF770853 & genseq-4 COI \\
\hline USNM 406025, CUR 11025 & KF770855 & genseq-4 COI \\
\hline USNM 426806, CUR 13218 & KF770875 & genseq-4 COI \\
\hline USNM 426807, CUR 13226 & KF770877 & genseq-4 COI \\
\hline USNM 426814, CUR 13259 & KF770880 & genseq-4 COI \\
\hline USNM 426812, CUR 13260 & KF770881 & genseq-4 COI \\
\hline \multicolumn{3}{|l|}{ Liopropoma carmabi } \\
\hline USNM 406374, CUR 11374 & KF770858 & genseq-4 COI \\
\hline USNM 414825, CUR 12032 & KF770861 & genseq-4 COI \\
\hline USNM 414826, CUR 12070 & KF770863 & genseq-4 COI \\
\hline USNM 414827, CUR 12071 & KF770864 & genseq-4 COI \\
\hline USNM 413959, CUR 13084 & KF770866 & genseq-4 COI \\
\hline USNM 413960, CUR 13085 & KF770867 & genseq-4 COI \\
\hline USNM 413961, CUR 13086 & KF770868 & genseq-4 COI \\
\hline USNM 422694, CUR 13099 & KF770869 & genseq-4 COI \\
\hline USNM 422687, CUR 13108 & KF770873 & genseq-4 COI \\
\hline \multicolumn{3}{|l|}{ Liopropoma eukrines } \\
\hline SIO 01-11, MCgroup 3333 & KF770885 & genseq-4 COI \\
\hline \multicolumn{3}{|l|}{ Liopropoma mowbrayi } \\
\hline USNM 420350, BLZ 5325 & JQ840569 & genseq-4 COI \\
\hline USNM 420349, BLZ 5326 & JQ840570 & genseq-4 COI \\
\hline BLZ 7720 (photo voucher only) & JQ841243 & genseq-5 COI \\
\hline USNM 406015, CUR 11015 & KF770854 & genseq-4 COI \\
\hline USNM 406131, CUR 11131 & KF770857 & genseq-4 COI \\
\hline USNM 406386, CUR 11386 & KF770859 & genseq-4 COI \\
\hline USNM 414815, CUR 12315 & KF770865 & genseq-4 COI \\
\hline
\end{tabular}




\begin{tabular}{|c|c|c|}
\hline Catalog Number/DNA Number & GenBank No. & GenSeq Designation \\
\hline USNM 422684, CUR 13101 & KF770870 & genseq- 4 COI \\
\hline USNM 422675, CUR 13103 & KF770871 & genseq-4 COI \\
\hline \multicolumn{3}{|l|}{ Liopropoma rubre } \\
\hline USNM 414697, BAH 9032 & KF770852 & genseq-4 COI \\
\hline USNM 419340, BLZ 5117 & JQ840571 & genseq-4 COI \\
\hline USNM 416331, BLZ 6236 & JQ840899 & genseq-4 COI \\
\hline USNM 416379, BLZ 6377 & JQ840900 & genseq-4 COI \\
\hline USNM 416009, BLZ 7806 & JQ841244 & genseq-4 COI \\
\hline USNM 415207, BLZ 8050 & JQ841640 & genseq-4 COI \\
\hline USNM 415226, BLZ 8095 & JQ841637 & genseq-4 COI \\
\hline USNM 415180, BLZ 8153 & JQ841638 & genseq-4 COI \\
\hline USNM 415181, BLZ 8154 & JQ841641 & genseq-4 COI \\
\hline USNM 415244, BLZ 8167 & JQ841639 & genseq-4 COI \\
\hline USNM 414498, CUR 8332 & JQ842192 & genseq-4 COI \\
\hline USNM 414499, CUR 8333 & JQ842193 & genseq-4 COI \\
\hline \multicolumn{3}{|l|}{ Liopropoma lunulatum (Pacific) } \\
\hline MBIO 1710 (no photo or specimen voucher) & JQ431889 & no classification \\
\hline MNHN 2008-1023, MBIO 1472 & JQ431888 & genseq-4 COI \\
\hline \multicolumn{3}{|l|}{ Liopropoma tonstrinum (Pacific) } \\
\hline USNM 425632, MOOP37 & KJ526149 & genseq-4 COI \\
\hline USNM 425630, MOOP38 & KJ526150 & genseq-4 COI \\
\hline \multicolumn{3}{|l|}{ Liopropoma pallidum (Pacific) } \\
\hline MNHN 2009-0793, MBIO 961 & JQ431890 & genseq-4 COI \\
\hline MNHN 2009-0794, MBIO 962 & JQ431891 & genseq-4 COI \\
\hline \multicolumn{3}{|l|}{ Bathyanthias mexicanus } \\
\hline FWRI 20709 (DNA number same) & KF770884 & genseq-4 COI \\
\hline \multicolumn{3}{|l|}{ Bathyanthias sp. } \\
\hline USNM 407791, MOC 11791 & KF770886 & genseq- 4 COI \\
\hline \multicolumn{3}{|l|}{ Outgroup Taxa } \\
\hline \multicolumn{3}{|l|}{ Grammistes sexlineatus } \\
\hline MNHN 2008-1105, MBIO 1671 & JQ431776 & genseq- 4 COI \\
\hline \multicolumn{3}{|l|}{ Rypticus carpenteri } \\
\hline USNM 401296, TOB 9102 & JN828097 & genseq-4 COI \\
\hline \multicolumn{3}{|l|}{ Scorpaena plumieri } \\
\hline USNM 406401, CUR 11401 & KF770860 & genseq-4 COI \\
\hline
\end{tabular}

